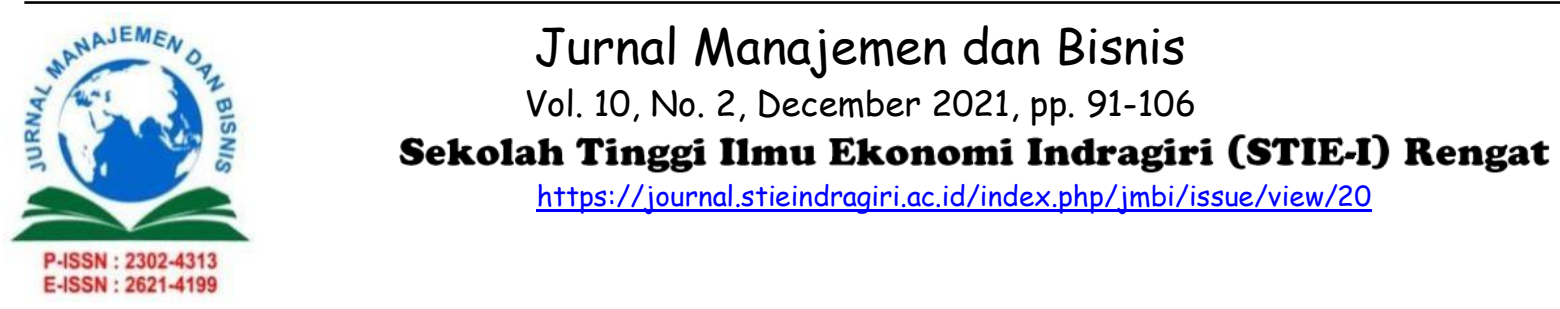

\title{
INFLUENCE COMPANY SIZE, CAPITAL STRUCTURE, DIVIDEND POLICY ON FINANCIAL PERFORMANCE WITH BIODIESEL PRODUCTION AS MODERATING VARIABLES IN PALM OIL PROCESSING COMPANIES ON THE INDONESIA STOCK EXCHANGE (IDX)
}

\author{
Winarsih $^{\text {1) }}$ Yulia Efni ${ }^{2)}$ Andewi Rokhmawati ${ }^{3)}$ \\ ${ }^{1}$ Students of the Postgraduate Management Program at Riau University \\ ${ }^{2)}$ Postgraduate Lecturer at the Faculty of Economics, Riau University \\ ${ }^{3)}$ Postgraduate Lecturer at the Faculty of Economics, Riau University \\ willysp2011@gmail.com \\ Submited: 2021.11.17 Reviewed: 2021.11.20 Accepted: 2021.12.31 \\ https://doi.org/10.34006/jmbi.v10i2.353
}

\begin{abstract}
This study aims to determine and analyze firm size, capital structure, dividend policy on the company's financial performance. To analyze biodiesel production strengthen the relationship between firm size, capital structure, dividend policy and company financial performance. The population in this study is the use of company data included in the palm oil processing sector companies that went public on the Indonesia Stock Exchange (IDX) in the period 2014 to 2019. The sample in this study was 12 companies that met the sampling characteristics that has been determined. The analytical technique used in this research is PLS Structural Equation Modeling (SEM) which is operated through the WarpPLS.5.O program. The results of the study show that the size of the company and capital structure on financial performance. Dividend policy has no effect on financial performance. Company size, capital structure have a significant effect on financial performance with Biodiesel Production as a Moderating Variable. The results of financial research on dividend policy have no effect on company performance with biodiesel production as a moderating variable.

Keywords: Company Size, Capital Structure, Dividend Policy, Biodiesel Production and Financial Performance

INTRODUCTION

The capital market is a gathering place for both potential investors and investors who have made previous transactions with parties who need funds for a long period of time. Investors and potential investors will be offered various options to view or measure the profits obtained in the form of rewards within a predetermined period of time in accordance with expectations.
\end{abstract}

Vol. 10, No. 2, December 2021, pp. 91-106

https://doi.org/10.34006/jmbi.v10i2.353 
Due to the increasingly rapid competition in the capital market in the current era of globalization, of course the challenge for companies to be able to maintain the sustainability of the company is getting bigger and still exists in the capital market. This is because, as we all know, competition is inevitable but must be faced by continuously increasing the company's competitive advantage. This is due to the demands of every investor who always wants income or profit on the funds they have invested in the company. This will be the first step for the company's sustainability (corporate sustainability) and will ultimately improve the company's financial performance (financial performance).

The company's financial performance is a reflection of how well the company's management refers to the financial statements that have been published in a certain period which is usually measured from the aspects of capital adequacy, liquidity, and profitability (Jumingan, 2006). The company's financial performance is very important for investors in considering investment decisions in a company.

Palm oil is one of the mainstay plantation commodities in Indonesia which plays an important role in the Indonesian economy. The Indonesian palm oil agribusiness industry has a competitive advantage to compete at the global level (Utomo, 2016). The decline in Crude Palm Oil (CPO) prices in Indonesia was influenced by European market demand. This of course makes sales of Palm Oil commodity products decrease. Phenomena that occur like this will affect the company's financial performance in the future, supported by the current financial condition alone is not enough to ensure financial performance grows in a sustainable manner. Therefore, in order to realize good and sustainable business conditions, companies are required to create businesses that are economically profitable,

However, in fact, if reviewed in depth, the thing that underlies the decline in CPO prices in Indonesia is not only the decline in European market demand, but as we know that Indonesia is currently experiencing an oversupply of CPO, namely high CPO production but not accompanied by an oversupply of CPO. increasing market demand. One of the government's strategies to deal with this problem is to encourage biodiesel consumption in the domestic market. The government wants the use of environmentally friendly fuel (biofuel) based on biodiesel to increase from year to year. If the company only focuses on revenue from $\mathrm{CPO}$, it is feared that financial performance will decline so that it is not as expected by the company.

Biodiesel is also superior to fossil fuels because it has a lower pollutant effect. Based on information from the Ministry of Energy and Mineral Resources (ESDM), biodiesel has low emissions because it is easily degradable. In addition, the presence of biodiesel as an alternative energy also reduces dependence on fuel oil (BBM) and the most important thing is to maximize the consumption of the CPO. Biodiesel itself is processed by PT. Pertamina (Persero) and PT. AKR Corporindo while the material is obtained through a biodiesel supplier company, this is stated in the Decree of the Minister of Energy and Mineral Resources Number 3756K /10/ MEM/2017 concerning the Establishment of Biodiesel Business Entities and Allocation of Volumes for the Procurement of Biofuels (BBN). ) Type of Biodiesel.

From the investor's point of view, one of the important indicators to assess the company's prospects in the future is to see the extent to which a company's performance can be seen through the company's profitability. This study uses a profitability ratio, namely Return on equity (ROE) to measure the company's performance. According to Brigham and Houston (2012: 133), the most important financial ratio to improve financial performance is return on equity. Return on equity is net profit for shareholders divided by total shareholder equity. Profitability of own capital or return on equity shows the company's ability to create 
profits or profits from its own capital. The higher the ROE, the higher the investor confidence. Investors will have more confidence in companies that can manage their capital well and provide benefits to them. Thus, Return on Equity (ROE) is an important indicator to assess the company's prospects in the future. Shareholders want to get a high rate of return or return on the capital they invest. If the ROE value is high, the stock price will tend to be high. With the increase in stock prices, it shows an increase in the value of the company which then increases the prosperity of shareholders. Shareholders want to get a high rate of return or return on the capital they invest. If the ROE value is high, the stock price will tend to be high. With the increase in stock prices, it shows an increase in the value of the company which then increases the prosperity of shareholders. Shareholders want to get a high rate of return or return on the capital they invest. If the ROE value is high, the stock price will tend to be high. With the increase in stock prices, it shows an increase in the value of the company which then increases the prosperity of shareholders.

To see the average development of Return On Equity (ROE) in Palm Oil Processing companies on the Indonesia Stock Exchange, see the following figure:

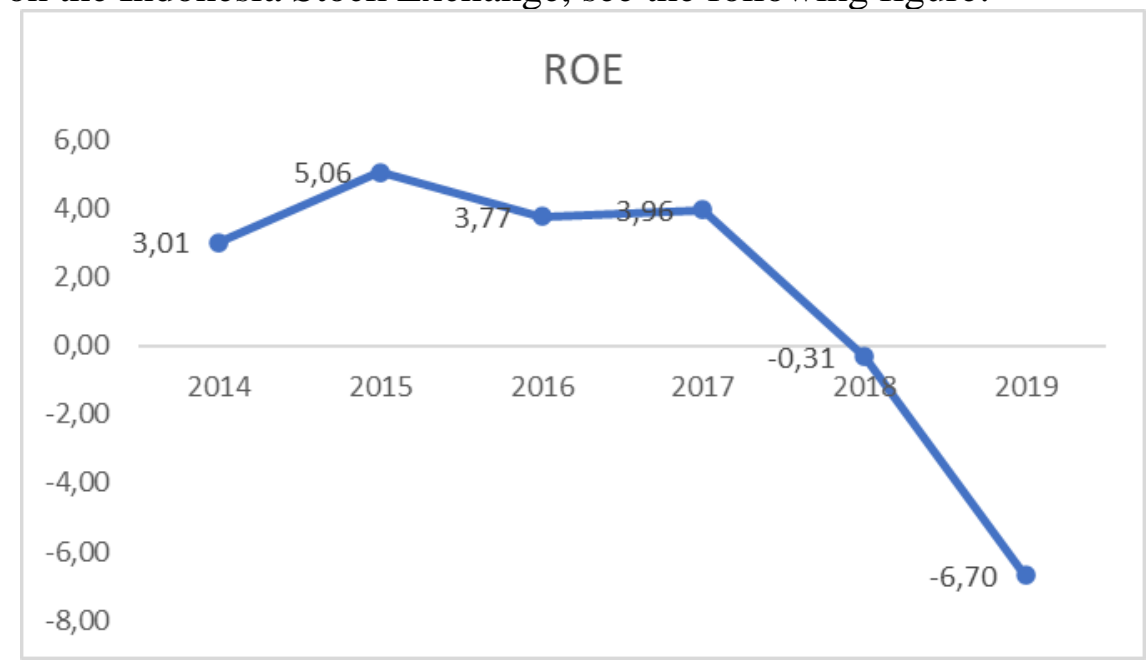

Figure 1 Company ROE

Source: Processed Data, 2021

Figure 1 shows that the company's return on equity from 2014-2019 has decreased and increased, even in the last two years, namely in 2018 and 2019 it experienced a significant decline. This decrease indicates that the company's ability to process its capital is not good enough so that it does not achieve the desired profit. Of course, this is not in line with the policy that has been made by the government which has actually increased the selling price of biodiesel, with a high selling price of course it will provide high profits. If this is not immediately corrected, it will certainly disappoint the shareholders because shareholders want to get a high return on the capital they have invested.

According to Brigham \& Houston, (2012: 146) factors that can affect the financial performance of a company, including company size, capital structure and dividend policy. Firm size can be seen from the total assets owned by the company that can be used for the company's operational activities. If the company has large total assets, the management is more flexible in using the existing assets in the company. The freedom that management has is proportional to the concern felt by the owner over his assets. A large number of assets will reduce the company's financial performance when viewed from the side of the company owner. However, when viewed from the management side, the ease with which it controls the company will improve the company's performance. 
The large size of the company makes it easier for companies to deal with funding problems. Companies generally have high flexibility and accessibility in terms of funding through the capital market. This convenience can be captured as good information. The size of a large and growing company can reflect the level of profit in the future (Suharli, 2006).

The next factor that can improve the company's financial performance is how the company makes funding decisions. Good funding decisions can be seen from the company's capital structure. Own capital structure is a funding decision related to the composition of debt, both long-term debt and short-term debt, preferred stock and common stock that will be used by the company. According to Munawir (2001), capital structure is the right or share owned by the owner of the company in the post of capital (share capital), retained earnings or profits or excess assets owned by the company over all its debts.

The next factor that can affect performance is dividend policy. Dividend policy concerns the issue of the use of profits which are the rights of shareholders. In this case, should the profits be divided as dividends or held back for reinvestment while still taking into account the company's goal of increasing the value of the company. Because by maximizing the value of the company, the owner of the company will become more prosperous (Husnan, 2013: 7).

In this study, dividend policy is measured by the Dividend Payout Ratio (DPR). Dividend policy is interesting to discuss because there are investors who prefer more certain dividends than uncertain future capital gains, while there are also those who prefer capital gains because they seek stable income from their investments. From the company's point of view, if the company chooses to distribute profits as dividends, it will reduce retained earnings and further reduce the total sources of internal funds or internal financing. On the other hand, if the company chooses to withhold the profits earned, then the ability to form internal funds will be even greater.

Value addedin this study is the issue of companies experiencing problems and including the biodiesel production variable as a moderating variable. This was done because several previous studies obtained results that were influential and some were not influential, this provided inconsistent evidence without using mediating variables.

Based on the background that has been described previously, the author intends to carry out research into the form of a thesis with the title: Effects of Company Size, Capital Structure, Dividend Policy on Financial Performance With Biodiesel Production as Moderating Variable in Palm Oil Processing Companies on the Indonesia Stock Exchange (IDX).

\section{LITERATURE REVIEW AND HYPOTHESES}

\section{Financial performance}

Company performance can be regarded as a formal effort carried out by the company to evaluate the efficiency and effectiveness of the company's activities that have been carried out in a certain period of time. According to Sucipto (2003:6) the notion of financial performance is "the determination of certain measures that can measure the success of an organization or company in generating profits".

Performance measurement is defined as "performing measurement", namely the qualifications and efficiency and effectiveness of the company in operating the business during the accounting period. Thus the notion of performance is a formal effort carried out 
by the company to evaluate the efficiency and effectiveness of the company's activities that have been carried out in a certain period of time (Hanafi, 2007:69).

Performance appraisal according to Srimindarti (2006:34) is "determining the effectiveness of operations, organizations and employees based on the targets, standards and criteria that have been set previously periodically". There are two kinds of performance, namely operational performance and financial performance. Operational performance is more emphasized on the company's internal interests such as branch/division performance as measured by speed and discipline. Meanwhile, financial performance is more about evaluating the company's financial statements at a certain time and period.

To find out the company's financial performance, it is generally necessary to analyze the financial statements, which according to Brigham and Houston (2007:78) include (1) comparing the company's performance with other companies in the same industry and (2) evaluating the tendency of the company's financial position over time. . The company's financial statements report both the company's position at a certain time and its operations over several past periods.

From the above understanding it can be concluded that financial performance is a formal business that has been carried out by a company that can measure the company's success in generating profits, so that it can see the prospects, growth, and potential for good development of the company by relying on existing resources. A company can be said to be successful if it has achieved the standards and objectives that have been set.

\section{Company size}

Company size describes the size of a company shown in total assets, total sales and average sales. Bambang Riyanto (2011: 305). According to Torang (2012), company size is a context variable that measures the demands of an organization's services or products. According to Werner R. Murhadi (2013) Firm Size is measured by transforming the company's total sales into the form of a natural logarithm. Company size is proxied using Log Natural Total Sales with the aim of reducing excessive data fluctuations. By using natural $\log$, sales of hundreds of billions or even trillions will be simplified, without changing the proportion of the actual sales of biodiesel.

According to Brigham and Houston (2006), firm size is the average total net sales for the year up to several years. In this case, sales are greater than variable costs and fixed costs, so the amount of income before tax will be obtained. Conversely, if sales are less than the variable costs and fixed costs, the company will suffer losses.

Basically the size of the company is only divided into three categories, namely large companies (large firms), medium companies (medium size), and small companies (small firms). According to Law No. 9 of 1995 concerning small businesses, it is explained that companies that have annual sales results explain that companies that have annual sales of at most Rp. 1,000,000,000,- (one trillion rupiah) are classified into small business groups. . With this provision, it can be stated that companies with annual sales of more than Rp. $1,000,000,000$,- (trillion billion rupiahs) can be grouped into medium and large industries.

So it can be concluded that the larger uThe size of companies classified include: total assets, sales log size, number of employees, and others. The larger the items, the larger the size of the company. The bigger the assets, the more capital invested, the more sales, the more money circulation, and the bigger the market capitalization, the bigger the company is known to the public and will affect the size of the company. 


\section{Capital Structure}

Capital structure is a balance or comparison between foreign capital and own capital. Foreign capital in this case is long-term and short-term debt. Meanwhile, own capital is divided into retained earnings and company ownership.

The optimal capital structure is the capital structure that optimizes the balance between risk and return so as to maximize share prices. For this reason, in determining the capital structure of a company, it is necessary to consider various variables that influence it.

The capital structure according to Sartono (2010: 225) is defined as follows: "The capital structure is a balance of the amount of permanent short-term debt, long-term debt, preferred stock and common stock." So the capital structure is a balance between the amount of short-term debt, long-term debt and shares.

The capital structure according to Sudana (2011:143) is defined as follows: "The capital structure is related to the long-term spending of a company as measured by the comparison of long-term debt with its own capital." So the capital structure is a comparison between long-term debt and own capital used for company spending

\section{Dividend Policy}

Dividendis a form of distribution of profits or profits to shareholders in a certain period based on the number of shares owned. That is, the amount of dividends depends on the size of the shares of each owner.

According to Sartono (2011) "dividend policy is a decision whether what the company earns will be distributed to shareholders as dividends or will be retained in the form of retained earnings to finance investment in the future". If the company chooses to distribute profits as dividends, it will reduce retained earnings and further reduce the total source of internal financing. On the other hand, if the company chooses to withhold the profits earned, then the ability to form internal funds will be even greater.

A company may not distribute dividends with the aim of using profits to expand or develop the business. However, in general, companies issue dividends to increase shareholder confidence in the long term, as well as attract new investors who are looking for a steady source of income.

Management has 2 (two) alternatives for recognizing the company's net income after tax: 1) it is distributed to the company's shareholders in the form of dividends, and 2) it is reinvested in the company as retained earnings. In general, as EAT (Earning After Tax) it is divided in the form of partly being reinvested. This means that management must make decisions about the amount of EAT to be distributed as dividends. Making decisions about dividends is called dividend policy. Atmaja (2008).

\section{Biodiesel Production}

Biodiesel is one of the potential petroleum substitute products and has quite promising prospects. In addition to a fairly competitive selling value, this product is considered environmentally friendly and is renewable energy because it uses plant raw materials (palm oil). Technically, biodiesel production can be done as a substitute for petroleum, making biodiesel prices more expensive. Efforts to intensify technology and production efficiency still have the opportunity to make biodiesel the main substitute for petroleum which is increasingly depleting in availability. (Tety, 2012)

The types of Biodiesel are as follows:

1. B20. B20 is a Government program that requires mixing $20 \%$ Biodiesel with $80 \%$ diesel fuel type, which produces B20 Biodiesel products. This program has been implemented 
since January 2016 according to the regulation of the Minister of Energy and Mineral Resources (ESDM) Number 12 of 2015 concerning the third amendment to the regulation of the Minister of Energy and Mineral Resources number 32 of 2008 concerning the supply, utilization and trading system of Biofuel as other fuels. .

2. B30. B30is a government program that requires mixing $30 \%$ of biodiesel with $70 \%$ of diesel fuel, which produces B30 biodiesel. This program will be implemented starting January 2020 in accordance with the regulation of the Minister of Energy and Mineral Resources (ESDM) Number 12 of 2015 concerning the third amendment to the regulation of the Minister of Energy and Mineral Resources number 32 of 2008 concerning the supply, utilization and trading system of Biofuel as another fuel. .

3. B100. B100is a term for Biodiesel which is a biofuel for diesel engine/motor applications in the form of fatty acid methyl ester (FAME) which is made from vegetable oil or animal fat through an esterification/transesterification process. The transesterification process is the process of removing alcohol from the ester, but what is used as a catalyst (a substance used to speed up the reaction rate) is alcohol or methanol.

\section{Research Framework}

Based on the theory that has been obtained, the researchers developed a research framework as follows:

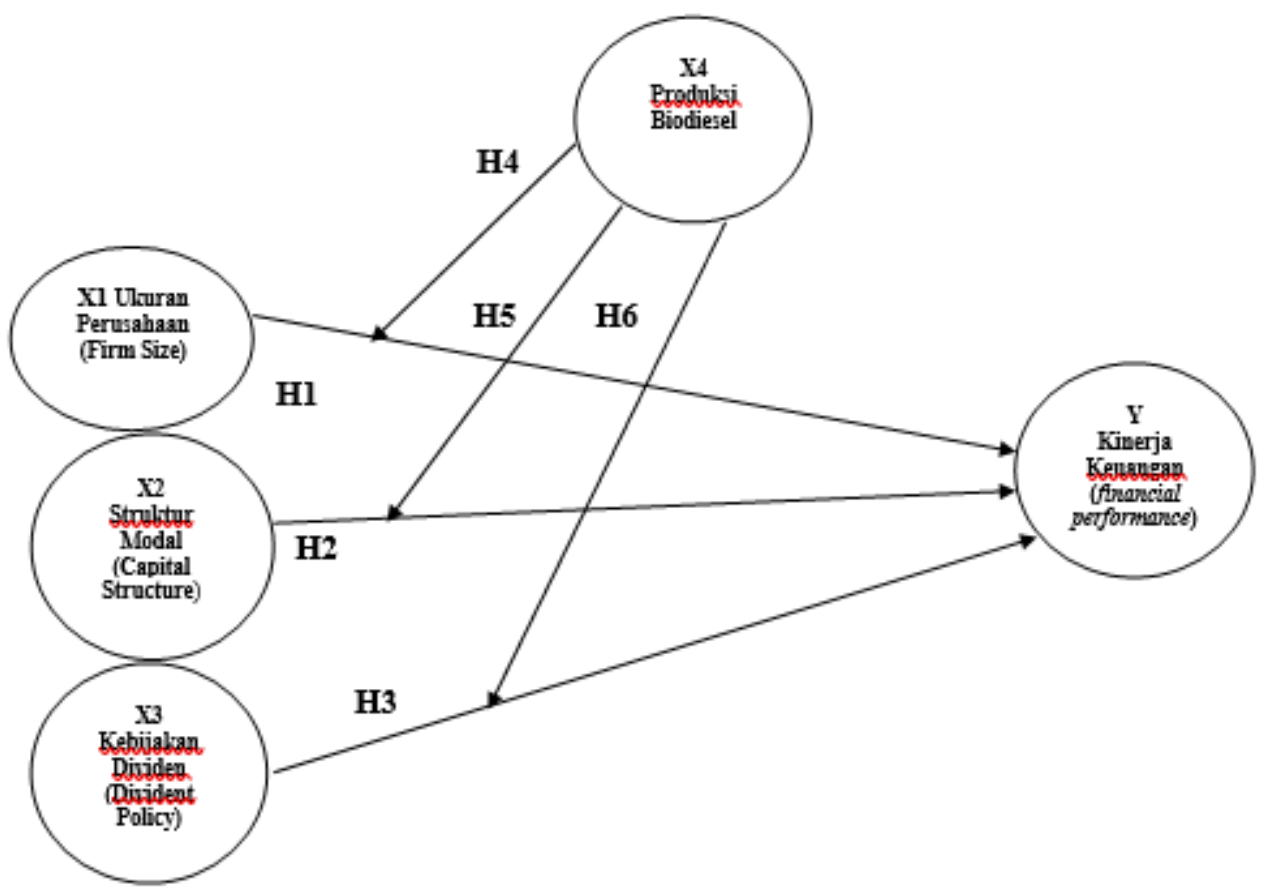

Figure 2 Research Model

\section{Hypothesis}

Based on the description and results of previous research and current research, the proposed hypothesis is:

H1: Firm size has a significant effect on financial performance

$\mathrm{H} 2$ : Capital structure has a significant effect on financial performance

H3 : Dividend policy has a significant effect on financial performance

$\mathrm{H} 4$ : Biodiesel production strengthens the effect of firm size on firm financial performance as a moderating variable. 
H5: Biodiesel production strengthens the effect of capital structure on the company's financial performance as a moderating variable.

H6: Biodiesel production strengthens the effect of capital structure on the company's financial performance as a moderating variable.

\section{RESEARCH METHODS}

\section{Research Approach}

Research design is all research processes carried out by the author in carrying out research from planning to carrying out research carried out at a certain time. This study uses a quantitative design with PLS structural equation modeling (SEM). PLS Structural Equation Modeling (SEM) which is operated through the WarpPLS.5.0 program is used to test how much of the contribution shown by the path coefficient on each path diagram of the causal relationship between variables $\mathrm{X} 1, \mathrm{X} 2, \mathrm{X} 3$, to variable $\mathrm{Y}$ which is moderated by variable $\mathrm{XM}$. Therefore it can be said that basically, SEM is a combination of factor analysis and multiple regression analysis (Ferdinand, 2011:11)

\section{Object of research}

The object of this research is the palm oil processing sector companies listed on the Indonesia Stock Exchange (IDX) which are listed as effective with an observation period of 5 (five) years from 2014 to 2019.

\section{Data Types and Sources}

The data used in this study are secondary data types. Secondary data is data collected indirectly from the source. Secondary data is usually collected by data collection agencies and published to the data user community.

\section{Population and Sampling Techniques Population}

The population in this study uses data from companies included in the palm oil processing sector companies that went public on the Indonesia Stock Exchange (IDX) in the period 2014 to 2019. The data used are data that have been published on the Indonesia Stock Exchange ( BEI).

\section{Sampling technique}

The sample is part of the number and characteristics possessed by the population (Sugiyono, 2014). The sample in this study used the methodpurposive sampling. Purposive Samplingis a sampling technique based on certain criteria. In accordance with the purpose of this study which will analyze the internal and external factors of banking, the bank sample was selected by purposive sampling.

The sample according to Sekaran, 2006 is a set of population. Determination of the sample in this study based on purposive sampling. Where the sample companies are selected based on certain criteria. The criteria used to select the sample are as follows:

1. Palm Oil Processing Companies listed on the Indonesia Stock Exchange according to the classification of the Indonesian Capital Market Directory.

2. Palm Oil Processing Company that publishes financial reports from 2014-2019 in a row.

3. Palm Oil Processing Company that provides dividends for 5 (five) consecutive years. 

companies.

Based on these criteria, the companies studied in banking companies are 12

\section{Data collection technique}

The type of data used is quantitative data, namely data in the form of numbers which are then processed and interpreted to obtain meaning from the data. Quantitative data in this study were obtained from the Annual Financial Reports of each company during the research period.

This study uses historical data taken during the period 2014 to 2019 . The data to be obtained from published financial reports are the 2014 to 2019 financial statements of the sample companies that are accessed on the Indonesia Stock Exchange (IDX) listed on the internet. with site www.http://finance.yahoo.com/ and www.idx.co.id. Based on the data obtained, a systematic and objective discussion and analysis was carried out.

\section{Data analysis technique}

The data analysis used in this study is PLS structural equation modeling (SEM) which is operated through the WarpPLS.5.0 program. This research requires an analysis of data and its interpretation which will be used to answer research questions to uncover certain social phenomena. So that data analysis is a process of simplifying data into a form that is easier to read and interpret. The model that will be used in this study is a causality model or relationship of influence to test the proposed hypothesis, then the analytical technique used is SEM. As a structural equation model, WarpPLS.5.0 has been widely used in equations and management research.

\section{RESULTS AND DISCUSSION}

\section{Descriptive Statistical Results}

Descriptive statistics are a description of the summary of data from each variable that will be included in the testing process, the aim is to make it easier to understand the data, starting from the amount of data $(\mathrm{N})$, Average Value (Mean), Maximum Value, Minimum Value, Standard Deviation Data (Std Deviation). The descriptive variables used in this study are as follows:

Table 1. Descriptive Statistics

\section{Descriptive Statistics}

\begin{tabular}{lrrrrr} 
& N & Minimum & Maximum & mean & Std. Deviation \\
\hline Financial performance & 72 & .20 & 72.46 & 10.39 & 8.12 \\
\hline Company Size & 72 & 1199.00 & 12527.00 & 6707.84 & 2385.91 \\
\hline Capital Structure & 72 & .04 & .99 & .4819 & .26503 \\
\hline Dividend Policy & 72 & 3.90 & 960.00 & 84.80 & 17.10 \\
\hline Biodiesel Production & 72 & 23784.00 & 284702970.00 & 32977841.61 & 2178008.39 \\
\hline Valid N (listwise) & 72 & & & & \\
\hline
\end{tabular}

Source: Data Processing Results, 2021

From Table 1 above, it can be seen that the number of research samples is 72 observations from a sample of oil palm plantation companies on the Indonesia Stock Exchange. By rounding two decimal places, it can be seen that the average value of financial performance is 10.39 while the std.deviation is \pm 8.12 , next is the average company size with an average value of 6707.84 with a std.deviation of 2385.91, capital structure with an average of 0.4819 with std. deviation \pm 0.26503 , dividend policy with an average of 84.80 with std. 
deviation \pm 17.10 , and the biodiesel production studied with an average value of 32977841.61 with std. deviation \pm 2178008.39 .

\section{Evaluation of Structural Model or Inner model}

The next stage is to conduct a structural evaluation (inner model) which includes a model fit test (model fit), path coefficient, and R2. In the model fit test, there are 3 test indices, namely average path coefficient (APC), average R-squared (ARS) and average variance factor (AVIF) with APC and ARS criteria accepted on condition that $p$-value $<0.05$ and AVIF is smaller of 5.

\section{Model fit and quality indices}

Average path coefficient $(\mathrm{APC})=0.210, \mathrm{P}=0.015$

Average R-squared (ARS) $=0.577, \mathrm{P}<0.001$

Average adjusted R-squared (AARS) $=0.538, \mathrm{P}<0.001$

Average block VIF (AVIF) $=1.457$, acceptable if $<=5$, ideally $<=3.3$

Average full collinearity VIF $(\mathrm{AFVIF})=1.435$, acceptable if $<=5$, ideally $<=3.3$

Tenenhaus $\mathrm{GoF}(\mathrm{GoF})=0.760$, small $>=0.1$, medium $>=0.25$, large $>=0.36$

Sympson's paradox ratio $(\mathrm{SPR})=0.833$, acceptable if $>=0.7$, ideally $=1$

R-squared contribution ratio $(\mathrm{RSCR})=0.980$, acceptable if $>=0.9$, ideally $=1$

Statistical suppression ratio $(\mathrm{SSR})=1.000$, acceptable if $>=0.7$

Nonlinear bivariate causality direction ratio $(\mathrm{NLBCDR})=0.917$, acceptable if $>=0.7$

The following are the output results of the fit indices model presented in the table, namely:

Table 2 Model Fit Indices

\begin{tabular}{|l|c|c|c|c|}
\hline & Index & P-Value & Criteria & Description \\
\hline APC & 0.210 & 0.015 & $\mathrm{p}<0.05$ & Good \\
\hline ARS & 0.577 & $<0.001$ & $\mathrm{P}<0.05$ & Good \\
\hline AVIF & $\begin{array}{c}1,457 \\
\text { Good if }<5\end{array}$ & & AVIF $<5$ & Good \\
\hline
\end{tabular}

Source: Processed Data, 2021

The output results above explain that APC has an index of 0.210 with a p-value of 0.015 . Meanwhile, ARS has an index of 0.577 with a p-value $<0.001$. Based on the criteria, APC has met the criteria because it has a $p$ value of 0.05 . Likewise, the $p$-value of ARS is $p$ $<0.001<0.05$. The AVIF value that must be $<5$ has been met because based on the data, the AVIF value is 1.457 . Thus, the inner model can be accepted.

Furthermore, testing of the inner model or structural model is carried out to see the relationship between the construct, significance value and R-square of the research model. The structural model was evaluated using R-square for the dependent construct of the t-test and the significance of the coefficients of the structural path parameters. In assessing the structural model with warpPLS, it begins by looking at the R-square for each dependent latent variable. Table 3 is the result of R-square estimation using warpPLS. 
Table 3 R Square Financial Performance

\begin{tabular}{|l|c|}
\hline \multicolumn{1}{|c|}{ Financial performance } & $R$ Square \\
\hline Company Size & \multirow{2}{*}{0.538} \\
\cline { 1 - 1 } Capital Structure & \\
\hline Dividend Policy & \\
\hline
\end{tabular}

Source: Data processing with WarpPLS, 2021

Table 3 shows that the R-square value of the variable R-square of firm size, capital structure, dividend policy on financial performance is $53.8 \%$, while the rest is influenced by other variables outside the research.

\section{Moderating Effect Test}

The procedure for testing dividend policy as a mediating variable of the relationship between firm size, debt and ownership structure on financial performance. Figure 3 below shows the full model executed using WarpPLS 5.0.

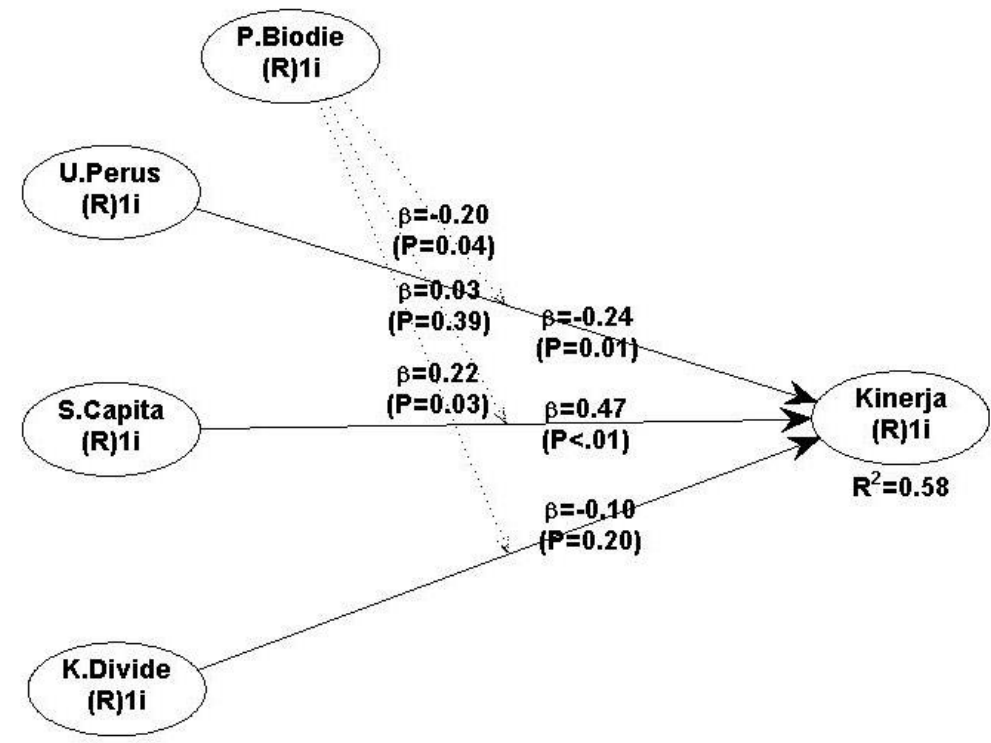

Source : Data processing with WarpPLS 5, 2021

Figure 3 Full Model

From Figure 3 above, it can be seen that the direct and indirect effects are shown in Table 4 below:

Table 4 Path Coefficients Direct and Indirect Effects

\begin{tabular}{|c|l|c|c|c|c|}
\hline \multirow{2}{*}{ No } & \multirow{2}{*}{ Track } & \multicolumn{2}{|c|}{ Direct Influence } & \multicolumn{2}{c|}{ Indirect Influence } \\
\cline { 3 - 6 } & & Coefficient & P-Value & Coefficient & P-Value \\
\hline 1 & Company Size-K.Keu & -0.245 & 0.014 & -0.198 & 0.039 \\
\hline 2 & $\begin{array}{l}\text { Capital Structure- } \\
\text { K.Keu }\end{array}$ & 0.471 & $<0.001$ & 0.031 & 0.394 \\
\hline 3 & $\begin{array}{l}\text { Dividend Policy- } \\
\text { K.Keu }\end{array}$ & -0.097 & 0.198 & 0.219 & 0.025 \\
\hline
\end{tabular}

Source: Data processing with WarpPLS, 2021 


\section{Hypothesis test}

The significance of the estimated parameters provides very useful information about the influence between the study variables. The basis used in testing the hypothesis is the value contained in the following output path coefficients:

\section{The Influence of Firm Size on Financial Performance}

Based on table 4 above, the effect of firm size on financial performance is significant with a path coefficient value of -0.245 , p-value 0.014 which indicates that there is an influence between firm size and financial performance. Thus, in this study, which states that "there is an influence between firm size on financial performance" is rejected.

\section{Effect of Capital Structure on Financial Performance}

Based on table 4 shows that the effect of capital structure on financial performance is significant with a path coefficient value of -0.471 , $p$ value 0.031 which indicates that there is an influence between capital structure and financial performance. Thus in this study which states that "capital structure affects financial performance" is accepted.

\section{The Effect of Dividend Policy on Financial Performance}

Based on table 4 shows that the effect of ownership structure on financial performance is not significant with a path coefficient value of -0.097 , $p$ Value $>0.198$ which indicates that there is no effect between dividend policy and financial performance. Thus in this study which states that "dividend policy affects financial performance" is accepted.

\section{Effect of Firm Size on Financial Performance Moderated Biodiesel Production}

Table 4 shows that the effect of firm size on financial performance moderated by biodiesel production is significant with a path coefficient value of $-0.198, p$ value of 0.039 which indicates that there is an effect of firm size on financial performance moderated by biodiesel production. Thus, in this study, which states that "biodiesel production strengthens the effect of firm size on firm financial performance as a moderating variable" is accepted.

\section{Effect of Capital Structure on Financial Performance Moderated Biodiesel Production}

Based on table 4 above, the relationship between capital structure and financial performance moderated by biodiesel production is significant with a path coefficient value of 0.031 , $p$ value 0.394 which indicates that there is no effect of capital structure on financial performance moderated by biodiesel production. Thus, in this study, which states that "biodiesel production strengthens the effect of capital structure on the company's financial performance as a moderating variable" is rejected.

\section{Effect of Dividend Policy on Financial Performance Moderated Biodiesel Production}

Based on table 4 above, the relationship between dividend policy and financial performance moderated by biodiesel production is significant with a path coefficient value of $0.219, \mathrm{p}$ value 0.025 , which indicates that there is no effect of dividend policy on financial performance moderated by biodiesel production. Thus, in this study the statement that 
"Biodiesel production strengthens the effect of capital structure on the company's financial performance as a moderating variable" is accepted.

\section{CONCLUSIONS AND SUGGESTIONS Conclusion}

Based on the analysis and discussion in the previous section, the following conclusions can be drawn.

1. Firm size has an effect on financial performance. The direct influence between the size of the company illustrates that the size of the company describes the size of a company which can be expressed by total assets. Thus the size of the company is a measure of the size of the assets owned by the company. The size of the company is often used as an indicator for the possibility of bankruptcy for a company, where companies with a larger size are seen as more capable of facing a crisis in running their business

2. There is a significant influence between capital structure on financial performance. This is because the Company must be able to make the right funding decisions considering the intense competition. The management of the company must have made financial decisions in order to increase the value of the company. That's why it's so important to make good financial decisions.

3. Dividend policy has no effect on financial performance. The ineffectiveness of this study shows that dividends distributed by companies tend to increase stock prices. An increase in stock prices means an increase in the company's financial performance.

4. Firm size has a significant effect on financial performance with Biodiesel Production as a Moderating Variable. The effect of this study shows that the biodiesel production of a company is able to strengthen the influence of company size on financial performance, the better the company in producing biodiesel, the company's financial performance will increase.

5. The results showed that the capital structure of the company's financial performance with biodiesel production as a moderating variable. The findings of this study show that every company needs capital and the obstacle in fulfilling it is the source of the capital provider, namely internal or external. The capitals collected from these various sources form the capital structure. Capital structure is a balance or comparison between longterm debt and own capital.

6. The results showed that dividend policy had no effect on the financial performance of companies with biodiesel production as a moderating variable. This shows that the company's biodiesel production has not been able to contribute to the decision to distribute dividends so that it can attract investors to invest which can further improve the company's performance. Dividend distribution offers can stimulate the company's growth rate, dividend distribution is used to attract investors to improve company performance.

\section{Research Limitations}

The limitations in this study are:

1. This study only uses the variables of firm size, capital structure and dividend policy as the dependent variable and the company's financial performance proxied by ROE as the dependent variable and biodiesel production as the moderating variable.

2. The observation period of this research is only from 2014-2019 in one company, namely an oil palm plantation company. 


\section{Suggestion}

Based on the results of the research that has been done, the researchers give some suggestions as follows.

1. Based on research, ROE below average is more than above average, this shows that the company has not been able to optimize the rate of return to generate profits as expected, therefore the company should increase earnings and earnings per share in order to increase profit growth.

2. For the company, so that the company is able to convey sufficient information to investors regarding the development of the company. In addition, the company can minimize the risk of investor confidence in investing their capital in the company, so that the value of the company increases and attracts investors to invest.

3. Investors are expected to be supervisors as well as controlling the flow of company funds so that they can be used for appropriate investments and not only benefit the company but also shareholders.

4. For further research, it is expected to develop research by adding other variables that affect dividend policy and financial performance.

\section{REFERENCE}

Agrestya. 2013. "Relationship between Company Assets and Performance". Yogyakarta: Gava Media.

Agus Harjito and Martono. 2007. "Financial Management". Yogyakarta, Ekonisia.

Agus, Sartono. 2011. "Financial Management Theory and Applications. Yogyakarta : BPFE. Agus Harjito and Martono. 2010. Financial Management. Yogyakarta: Echonesia.

Ahmad Komara, Sri Hartoyo \& Trias Andati 2014". Analysis of the Effect of Capital Structure on the Financial Performance of Financing Companies Listed on the Indonesia Stock Exchange in 2009-2013". Journal of Finance and Banking, Vol. 20 No.1 Pg 10-21.

Analysis, Y. 2011. "The Influence of Firm Size, Leverage, Profitability and Dividend Policy on Firm Value (Study of Manufacturing Companies Listed on the Stock Exchange in 2006-2008)".

Atmaja, Luke Setia. 2008. "Theory and Practice of Financial Management". Yogyakarta: Publisher Andi.

Bambang Riyanto. 2008. "Basics of Corporate Expenditure". Yogyakarta: Mr.

Brigham, Eugene F \& Houston Joel F. 2007.” Fundamentals of Financial Management", Edition 11, Book 1, Salemba four, Jakarta.

Brigham, Eugene F. \& Joel F. Houston. 2006. "Fundamentals of Financial Management". Translator: Ali Akbar Yulianto. Edition 10. Book 1. Jakarta: Salemba Empat.

Elly Lestari 2018". The Influence of Debt Policy and Dividend Policy on Financial Performance (Case Study on Companies that Go Public on the Indonesia Stock Exchange)". Vol 15 No 1.

Ermi Tety, Sakti Hutabarat \& Fajar Manggala Putra 2012". Prospects of Commodity Palm Oil (Cpo) in the Development of Biodiesel as an Alternative Fuel in Indonesia". Journal of Economics and Business Education, Vol. 4 No. 3 Pages 152-162.

Fachrudin. 2011. "Analysis of the Effect of Capital Structure, Company Size, and Agency Cost on Company Performance". Journal of Accounting and Finance, Xiii (1), 3746. 
Ghozali, Imam, 2009, Application of Multivariate Analysis With SPSS Program ". Semarang: Diponegoro University Publishing Agency.

Gilang Salman Al Farisi \& Nila Firdausi Nuzula 2019". Analysis of Differences in Indonesia Stock Exchange Reactions Before and After the Announcement of the Biodiesel Policy 20 (B20) (Study on Palm Oil Companies in the Plantation Subsector in 2018)". Vol 72 No. 1

Hadri Kusuma. 2005. "Factors Affecting Capital Structure of Manufacturing Companies Go Public on the Jakarta Stock Exchange". Journal of Masters in Management, Issn 1410-9018.

Hanafi, Mamduh H \& A. Halim. 2007. "Financial Statement Analysis". Edition 3. Yogyakarta : Publisher of UPP STIM YKPN.

I Made Sudana. 2011. "Company Financial Management Theory and Practice". Jakarta: Erlangga.

Iqbal Bukhari 2012". The Influence of Good Corporate Governance and Company Size on Corporate Financial Performance". (Empirical Study of Companies Listed on the IDX (2010)". Journal of Accounting, Vol. 1 No. 1.

Ira Wikartika \& Fajar Syaiful Akbar 2020". Effect of Institutional Ownership, Concentration of Ownership and Dividends on Company Performance". Journal of Business, Management and Banking, Vol. 6 No. 1.

Irwan Eka Putra 2012". Effect of Capital Structure on Financial Performance in Family Companies Listed on the Indonesia Stock Exchange (Year 2010)".

Joko Purwono, Sri Sugyaningsih \& Resty Istiarti 2015". Financial Performance Analysis of Go Public Palm Oil Companies in Indonesia (Case of PT Astra Agro Lestari Tbk, PT Sampoerna Agro Tbk, PT PP London Sumatra Indonesia Tbk, PT Tunas Baru Lampung Tbk and PT Sinar Mas Agro Resources and Technology Tbk)". Vol 9 No 2.

Joko Sukendro \& C. Ambar Pujiharjanto 2012". The Influence of Dividend Policy on Company Performance in Indonesia". Journal of Accounting and Management, Vol. 1 No. 2.

Friday. 2006. "Financial Statement Analysis". Jakarta: PT. Earth Literature.

Khaira Amalia Fachrudin .2011". Analysis of the Effect of Capital Structure, Company Size, and Agency Costs on the Performance of Chemical and Basic Industry Companies listed on the Indonesia Stock Exchange in 2009". Journal of Accounting and Finance, Vol. 13 No. 1

Munawir. S. 2004. "Financial Statement Analysis". Liberty Publishers. Yogyakarta.

Munawir. S. 2001. "Financial and Management Accounting". First edition. BPFE Publisher: Yogyakarta.

Munawir. S. 2012." Financial Information Analysis”. Liberty, Yogyakarta.

Murhadi Werner R. 2013. "Analysis of Projected Financial Statements and Stock Valuation". Jakarta: Salemba Empat.

Rafian Joni, E. Gumbira-Sa'id, Harianto \& Nunung Kusnadi 2010.” The Impact of the Development of the Biodiesel Industry from Palm Oil on Palm Oil Plantations and the Indonesian Palm Oil Industry." Journal of Industrial Technology. Vol. 20 No. 3

Srimindarti, 2006. "Balanced Scorecard as an Alternative for Measuring Performance". Semarang: STIE Stikubank.

Sucipto. 2003. Financial Performance Assessment. Journal of Finance, Postgraduate Program, University of North Sumatra, Medan. 
Suharli. 2006. "Empirical Study on the Effect of Profitability, Leverage and Stock Price on the Total Cash Dividend (Study on Companies Listed on the Jakarta Stock Exchange Period 2002-2003)". Journal of Management, Vol. 6 No. 2.

Sunariyah. 2010. "Introduction to Capital Market Knowledge Sixth Edition". UPP STIM YKPN: Yogyakarta.

Syamsir Torang. 2012. "Research Methods for Organizational Structure \& Behavior". Bandung: Alphabeta.

Tulus Prijanto, Andri Veno \& Chuzaimah 2017". The Effect of Firm Size and Liquidity on Company Performance (Empirical Study on Manufacturing Companies Listed on the Indonesia Stock Exchange Year (2013-2015)). Journal of Accounting, Vol 13 No 4.

Uma Sekaran, 2006. "Business Research Methods". Jakarta: Salemba Empat.

Wahyu Meiranto \& Ika Surya Martsila 2013 ". The Influence of Corporate Governance and Company Size on Corporate Financial Performance in Non-Financial Companies Listed on the Indonesia Stock Exchange for the Period 2009 - 2011". Accounting Journal, Vol. 2 No. 4 